\title{
FLOOD MODELLING OF BADENG RIVER USING HEC-RAS IN SINGOJURUH SUB- DISTRICT, BANYUWANGI REGENCY, EAST JAVA, INDONESIA
}

\author{
Syamsul Bachriं ${ }^{1}$, Yulius Eka Aldianto ${ }^{2}$, Sumarmi ${ }^{3}$, Kresno Sastro B U4, Moh Naufal F5 \\ Jurusan Geografi, Fakultas Ilmu Sosial, Universitas Negeri Malang \\ Jl. Semarang No. 5, Kota Malang, Jawa Timur, 65145, Indonesia \\ e-mail: syamsul.bachri.fis@um.ac.id
}

Received: 16 July 2020, Repaired: 24 December 2020, Approved: 25 December 2020

\begin{abstract}
The flood disaster is a severe threat in Indonesia due to the enormous impacts on environmental degradation, social and economic sectors. One flood event due to the overflow is the Badeng River's flooding in 2018 at Singojuruh Subdistrict, Banyuwangi Regency. The flood had a detrimental impact on the local community, especially on agricultural land and residential. Anticipatory steps need to be taken to minimize losses due to flooding in the future. Inundation modelling in this research is purposed to predict flood hazards. Hence it can have appropriate anticipatory steps in the future. The software used to model the inundation in this study was the HEC-RAS Program. Data needed in this study are river geometry, manning coefficient, and maximum daily rainfall from the year 2010 until 2019. The research e stages in this study consist of (1) Calculation of watershed morphometry, (2) Calculation of average regional rainfall, (3) Calculation of rainfall plan, (4) Rain Data Suitability Test, (5) Calculation of Rain Intensity, (6) Calculation of Flood Discharge Plan, (7) Geometry Modelling, (8) Extraction of Manning Coefficient, and (9) Inundation Simulation. The results of the Gama 1 method's peak discharge plan showed an increase in each return period. The area with the highest level of susceptibility around the Badeng River occurs in Alasmalang Village, Singojuruh Subdistrict. This area has the smallest river storage capacity than other river crossings. Hence it has the most significant potential for flooding.
\end{abstract}

Key words: inundation modelling, flood, HEC-RAS, Badeng River

\begin{abstract}
Abstrak
Bencana banjir menjadi ancaman serius bagi negara Indonesia karena memberikan dampak yang besar terhadap kerusakan lingkungan, sosial maupun ekonomi. Salah satu kejadiannya adalah banjir yang terjadi akibat luapan sungai Badeng pada tahun 2018 di Kecamatan Singojuruh, Kabupaten Banyuwangi. Kejadian Banjir tersebut memberikan dampak yang merugikan bagi masyarakat setempat, terutama pada lahan pertanian dan permukiman. Langkah antisipasi perlu dilakukan untuk meminimalisir kerugian akibat bencana banjir di masa mendatang. Pemodelan genangan dalam penelitian ini dibuat bertujuan untuk memprediksi bahaya banjir, sehingga dapat dilakukan langkah antisipasi yang tepat. Software yang digunakan untuk memodelkan genangan dalam penelitian ini adalah Program HEC-RAS. Data yang dibutuhkan berupa data geometri sungai, koefisien manning dan curah hujan harian maksimum selama periode tahun 2010 sampai 2019. Beberapa tahapan dalam penelitian ini meliputi (1) Perhitungan morfometri DAS, (2) Perhitungan hujan rerata wilayah, (3) Perhitungan curah hujan rencana, (4) Uji Kesesuaian Data Hujan, (5) Perhitungan Intensitas Hujan, (6) Perhitungan Debit banjir rencana, (7) Pemodelan geometri, (8) Ekstraksi angka kekasaran manning, dan (9) Simulasi Genangan. Hasil perhitungan debit puncak rencana metode Gama 1 menunjukkan peningkatan pada setiap periode ulang. Daerah yang mempunyai tingkat
\end{abstract}


kerawanan paling besar adalah areal sekitar Sungai Badeng yang berada di Desa Alasmalang Kecamatan Singojuruh. Daerah ini memiliki kapasitas tampung sungai yang paling kecil daripada penampang sungai yang lainnya, sehingga memiliki potensi terjadinya banjir paling besar.

\section{Kata kunci: pemodelan genangan, banjir, HEC-RAS, Sungai Badeng}

\section{INTRODUCTION}

Flood is a disaster that has a huge impacts within many countries. The impact of flooding effects on environmental, social and economic damage. Indonesia is one of the countries that experiences with the floods. Based on BNPB data (2019), there were 1276 flood events out of a total of 9385 all disasters in Indonesia in 2019.

Flood disasters caused by several factors, such as a high rainfall intensity, lack of drainage or river capacity, topographic conditions and massive land use change (Asdak, 2018; Farid et al., 2017). Rain intensity that exceeds infiltration capacity can result in runoff (Hadisusanto, 2010). The runoff will enter the river and increase the river flow rate. When the flow rate exceeds the river's carrying capacity, the water will have overflow situation, hence it can be inundate the area around the river. In addition, human activities also have an effect on flooding. Land use change from non-developed land to built-up land can cause a decrease in infiltration capacity (Kuntoro et al., 2017). A decrease in infiltration capacity can increase the occurrence of surface runoff. As surface runoff gets bigger, the potential for flooding will also increase.

Furthermore, river's inability to accommodate the volume of water also caused flooding in Singojuruh Subdistrict, Banyuwangi Regency in 2018. The flood occurred three times in 2018 and had an impact on residential and agricultural land. The impact of this flood is estimated to cause losses of around 5 billion, with details of 1,721 hectares of damaged rice fields and 23 houses damaged (Saksono, 2018).

Flood incident in the Badeng River can be used as a lesson to anticipate similar flooding events in the future. It is an urgent need to prepare the appropriate mitigation facing the floods. One approach that can be a solution is creating a flood hazard map through the flood modeling technique. Flood modeling is an essential aspect of reducing disasters at present and in the future (Kusratmoko et al., 2016).

$$
\text { HEC-RAS }
$$

(Hydrological

Engineering Center - River Analysis System) is an application program for modeling flow in rivers both in one-dimensional and twodimensional forms (Istiarto, 2014; US Army Corps of Engineers, 2016). There are four components in the HEC-RAS, namely: 1) permanent flow profile calculation, 2) nonpermanent flow simulation, both one dimension and two dimensions, 3 ) sediment transport count, and 4) water quality calculation. This program is used to analyze various hydraulic engineering problems, such as flood estimation, river capacity analysis, depth monitoring at each river point, and site selection to construct water structures (such as dams, pumping stations) (Hadžić et al., 2018). HEC-RAS program focuses on hydraulic analysis, which requires data in river cross-sections to determine the river holding capacity and hydrological data as flow input data.

This research is focused on inundation modeling due to the overflow of the Badeng River. The Badeng River originates at Mount Pendil, which is included in the Raung Volcano complex, while the downstream part is in the Rogojampi and Blimbingsari Districts. In addition, it is a continuation of previous research, where previous research only focused on the river carrying capacity without taking into account the rainfall parameters (Bachri et al., 2019). Meanwhile, in this study, rainfall parameters have been used and can display the area affected by inundation and information on its location and depth. The inundation modeling can be 
used as a reference for policymakers to determine the right steps in anticipating the danger of flooding in the future.

\section{RESEARCH METHOD}

This study focuses on hydrological data processing as material for HEC-RAS modeling. The stages of this research include data collection and data analysis (Hydrology and Hydraulics). Inundation modelling is the main work within the model. The data flow which is used in this research obtained from the flood discharge hydrograph calculation designed by the Gama 1 method. The results of the hydrograph calculation will become input data for inundation modeling using the HEC-RAS program. This modeling then analyzed the distribution of flood hazard areas in the Badeng River. The flow in this research can be seen in Figure 1. Also, the research location area is shown in Figure 2.

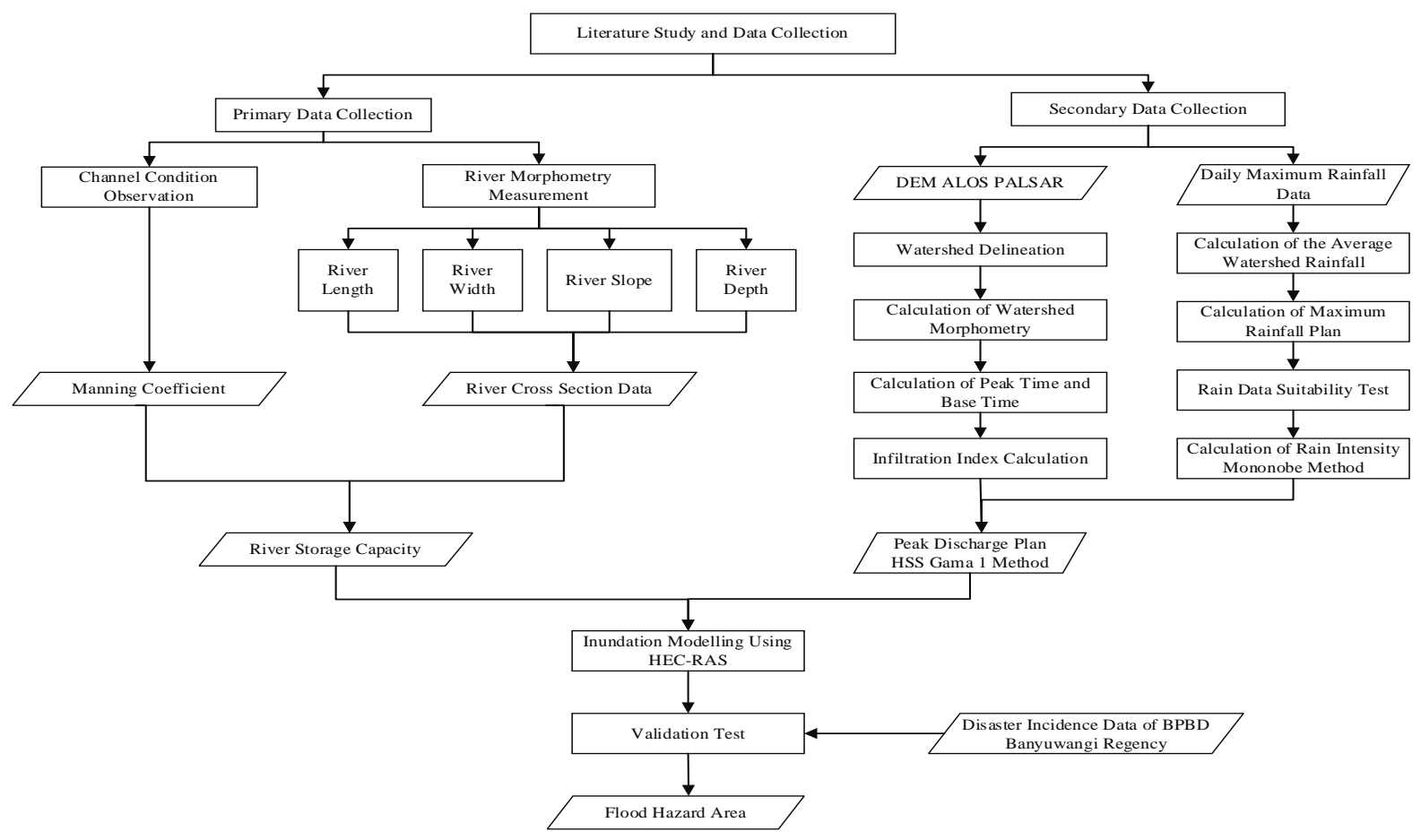

Figure 1. Research Flow of Flood Inundation Modelling of Badeng River

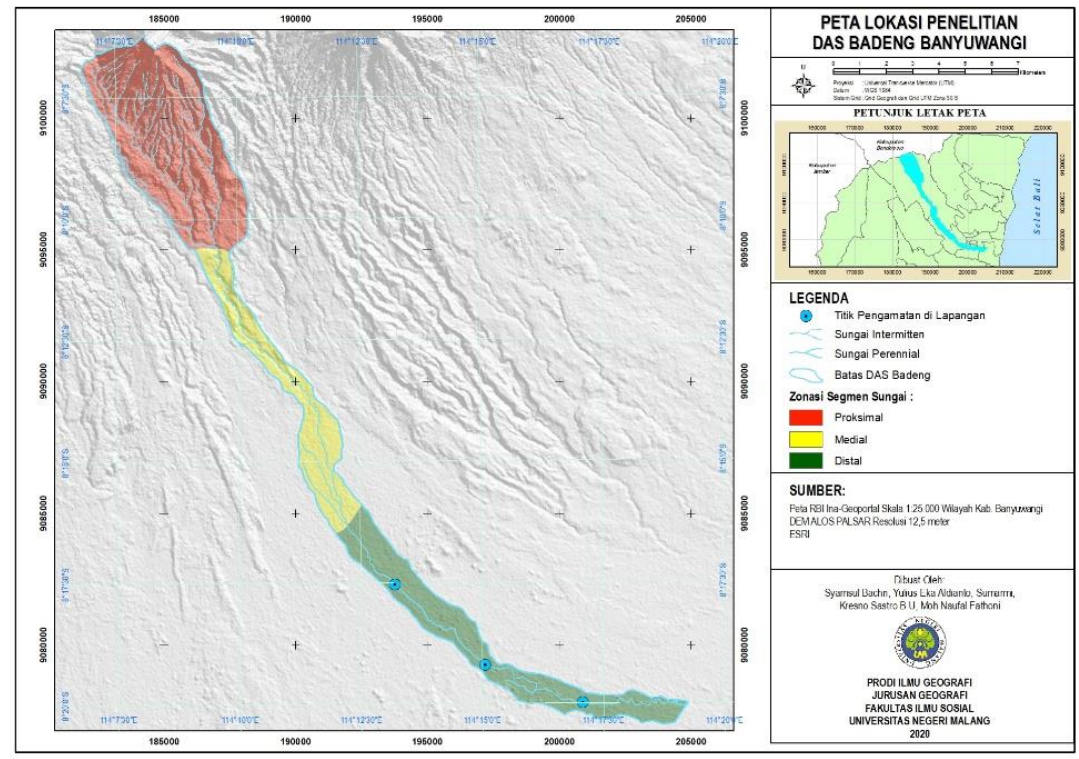

Figure 2. Research Location Map 


\section{Data collection}

The types of data used in this study include primary data and secondary data. Primary data is obtained directly from measurements and observations in the field, including river cross-sectional data, manning coefficient, and actual river discharge. River cross-sectional data used are river length, river width, river depth, and river slope.

The study's secondary data were DEM ALOS PALSAR data, maximum daily rainfall, and the RBI map of Banyuwangi Regency. DEM ALOS PALSAR has a spatial resolution of $12.5 \mathrm{~m}$ and can be downloaded from the Alaska Satellite Facility (ASF) Distributed Active Archive Center (DAAC) (Niipele \& Chen, 2019). This DEM data is used for processing morphometric data in the Badeng watershed. This watershed morphometric information is used for the calculation of the HSS Gama 1 variable. The maximum daily rainfall data used is 2010 to 2019 and is obtained from the Office of PU Pengairan. This data is used for the calculation of the flood discharge. The RBI map for Banyuwangi Regency was downloaded from Ina-Geoportal and utilized for the Badeng River's geometric analysis.

\section{Hydrological Analysis}

Hydrological analysis is carried out to predict the magnitude of flooding based on rainfall data at the studied location. There are several stages in reducing rainfall data to flood discharge, including: calculation of regional average rainfall, calculation of rainfall, test of suitability of rain data and calculation of flood discharge. The calculation of the mean rainfall in this study uses the Thiessen Polygon method. This method is the most widely used method and is suitable for areas with uneven rain stations (Hadisusanto, 2010; Triadmodjo, 2009).

The data from the regional average rainfall calculation is used to calculate the mean rainfall for a certain return period. The return periods used in this study were 2, 5, $10,25,50$ and 100 years. The method of calculating the rainfall plan used in the study was Log Pearson Type III. In calculating the rainfall in this plan, several statistical parameters are used, namely the mean, standard deviation, coefficient of variance, inclination coefficient and kurtosis coefficient (Upomo \& Kusumawardani, 2016).

The results of rain calculation are then used to calculate the flood discharge at a certain return period. The calculation of the flood discharge in this return period uses the Gama 1 method. This method has been developed based on the hydrological behavior of 30 watersheds in Java by Sri Harto (1993) in Triadmodjo (2009). The Gama 1 HSS is derived based on the physical parameters of the watershed. These parameters can be measured from the topographical map of the watershed under review (Handayani et al., 2016). The results of the discharge calculation are used as flow input data in the HEC-RAS program.

\section{Hydraulic Analysis}

Hydraulic analysis is a continuation of hydrological analysis (Harijadi, 2015). This analysis aims to determine the crosssectional capacity of the river to accommodate the discharge. The river holding capacity is known from the river cross-sectional data and the manning coefficient. From the river's carrying capacity, an inundation model can be made using the calculated flood discharge data. The hydraulic analysis in this study was carried out using the HEC-RAS program.

In HEC-RAS processing, there are three main steps for making inundation modeling. The three steps are: geometry modeling, flow modeling, and inundation simulation. The parameters required for geometric modeling are: river flow scheme, terrain data of the research location, the perimeter of the study site, roughness coefficient (manning coefficient) and upstream and downstream boundary data. After the river geometry data has been inputted, it is followed by entering the flow data from the results of the flood discharge calculation of the Gama 1 method. The flow 


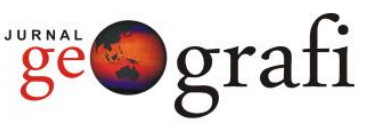

data used is hydrograph data, then the menu used is Unsteady Flow Data. After all the geometry and flow data are entered, a running process is carried out on the HECRAS to simulate the inundation. The data obtained from the inundation simulation are the extent and depth of the inundation area.

\section{RESULT AND DISCUSSION Flood discharge calculation}

The main parameter needed to calculate flood discharge is rainfall - the first stage in processing rain data in calculating the regional average rainfall using the Thiessen polygon method. The average rain calculation needs to be done because there are more than one rain gauge stations in the research location. The results of the analysis of the regional average rainfall can be seen in table 1 .

\section{Table 1. Average Regional Rainfall}

\begin{tabular}{ccr}
\hline No & Year & $\begin{array}{c}\text { Maximum Average Rainfall } \\
(\mathrm{mm})\end{array}$ \\
\hline 1 & 2010 & 131.451 \\
2 & 2011 & 73.758 \\
3 & 2012 & 79.999 \\
4 & 2013 & 114.882 \\
5 & 2014 & 133.890 \\
6 & 2015 & 72.035 \\
7 & 2016 & 136.846 \\
8 & 2017 & 109.276 \\
9 & 2018 & 139.875 \\
10 & 2019 & 100.953 \\
\hline
\end{tabular}

The calculation of the mean rainfall for the area above is used to calculate rain. The results of the rainfall calculation can be seen in table 2 . The calculation of the rainfall then carried out the suitability test using the Chi-Square and Smirnov-Kolmogorov methods. The test aims to determine the suitability between the calculation results and existing rain data (Hadisusanto, 2010). The test results with a significant degree of $5 \%$ indicate that the level of conformity between the calculation results and the rain data is acceptable.

Table 2. Rainfall Calculation

\begin{tabular}{ccccc}
\hline $\begin{array}{c}\text { Return } \\
\text { Periods } \\
\text { (Year) }\end{array}$ & $\begin{array}{c}\text { Log } \\
\text { (Xaver } \\
\text { age) }\end{array}$ & $\mathrm{k}$ & Log $($ Xtr $)$ & $\begin{array}{c}\text { Rainfal } \\
\text { Plan } \\
(\mathrm{mm})\end{array}$ \\
\hline 2 & 2.03 & 0.083 & 2.039592 & 109.545 \\
5 & 2.03 & 0.856 & 2.128923 & 134.562 \\
10 & 2.03 & 1.216 & 2.170526 & 148.090 \\
25 & 2.03 & 1.567 & 2.211089 & 162.588 \\
50 & 2.03 & 1.777 & 2.235357 & 171.932 \\
100 & 2.03 & 1.955 & 2.255928 & 180.272 \\
\hline
\end{tabular}

The calculated rainfall data is still in the form of daily rainfall data. In calculating flood discharge, the rain data used is usually in the form of hourly rain depth (Triadmodjo, 2009). The daily rainfall data is derived into hourly rainfall data using the Mononobe method. The results of the calculation of rain intensity at each return period can be seen in table 3 .

Table 3. Rainfall Intensity Every Return Periods

\begin{tabular}{ccccccc}
\hline $\begin{array}{c}\text { Rainfall } \\
\text { Duration } \\
\text { (hour) }\end{array}$ & 2 & \multicolumn{5}{c}{ Return Periods } \\
\hline 1 & 37.977 & 46.650 & 51.340 & 56.366 & 59.606 & 62.497 \\
2 & 23.924 & 29.388 & 32.342 & 35.508 & 37.549 & 39.370 \\
3 & 18.257 & 22.427 & 24.682 & 27.098 & 28.655 & 30.045 \\
4 & 15.071 & 18.513 & 20.374 & 22.369 & 23.654 & 24.802 \\
5 & 12.988 & 15.954 & 17.558 & 19.277 & 20.385 & 21.374 \\
6 & 11.501 & 14.128 & 15.548 & 17.071 & 18.052 & 18.927 \\
7 & 10.378 & 12.748 & 14.030 & 15.404 & 16.289 & 17.079 \\
8 & 9.494 & 11.663 & 12.835 & 14.092 & 14.901 & 15.624 \\
9 & 8.777 & 10.782 & 11.866 & 13.027 & 13.776 & 14.444 \\
10 & 8.182 & 10.050 & 11.061 & 12.144 & 12.842 & 13.465 \\
11 & 7.678 & 9.432 & 10.380 & 11.396 & 12.051 & 12.636 \\
12 & 7.245 & 8.900 & 9.795 & 10.754 & 11.372 & 11.923 \\
13 & 6.869 & 8.438 & 9.286 & 10.195 & 10.781 & 11.304 \\
14 & 6.538 & 8.031 & 8.838 & 9.704 & 10.261 & 10.759 \\
15 & 6.244 & 7.670 & 8.441 & 9.267 & 9.800 & 10.275 \\
16 & 5.981 & 7.347 & 8.086 & 8.877 & 9.387 & 9.843 \\
17 & 5.744 & 7.056 & 7.765 & 8.525 & 9.015 & 9.453 \\
18 & 5.529 & 6.792 & 7.475 & 8.207 & 8.678 & 9.099 \\
19 & 5.334 & 6.552 & 7.210 & 7.916 & 8.371 & 8.777 \\
20 & 5.154 & 6.331 & 6.968 & 7.650 & 8.090 & 8.482
\end{tabular}




\begin{tabular}{lllllll}
21 & 4.989 & 6.129 & 6.745 & 7.405 & 7.831 & 8.211 \\
22 & 4.837 & 5.942 & 6.539 & 7.179 & 7.592 & 7.960 \\
23 & 4.696 & 5.768 & 6.348 & 6.969 & 7.370 & 7.727 \\
24 & 4.564 & 5.607 & 6.170 & 6.775 & 7.164 & 7.511 \\
\hline
\end{tabular}

After the rain data is obtained, the next step is calculating the discharge. The Gama 1 method is suitable for watershed conditions in Java Island with limited data availability (Marthina et al., 2014). The results of the calculation of watershed morphometric parameters can be seen in table 4 . These parameters are used to calculate the main HSS Gama 1 variables, namely the rise time $(\mathrm{TR})$, peak discharge (Qp), base time (TB), and storage coefficient $(\mathrm{K})$. The results of the calculation of the main variable HSS Gama 1 can be seen in table 5 .

Table 4. Morphometric Parameters of the Badeng Watershed

\begin{tabular}{lr}
\hline \multicolumn{1}{c}{ Parameters } & \multicolumn{1}{c}{ Result } \\
\hline Length of the Main River (L) $(\mathrm{km})$ & 32.157 \\
Watershed Width 1/4 L (WL) $(\mathrm{km})$ & 0.95 \\
Watershed Width 3/4 L (WU) (km) & 2.51 \\
Watershed Area (A) (km2) & 57.912 \\
Upstream Watershed Area (Au) (km2) & 33.233 \\
Number of River Meetings (JN) & 46 \\
Total River Network of Level 1 (P1) & 44 \\
Total River Network of All Level (PN) & 82 \\
Total River Length of Level 1 (L1) (km) & 55.93 \\
Total River Length of All Levels (LN) $(\mathrm{km})$ & 112.82 \\
Slope of the Main River (S) & 0.022 \\
SF & 0.4957454 \\
SN & 0.5365854 \\
WF & 2.6421053 \\
RUA & 0.5738534 \\
SIM & 1.5161812 \\
D & 1.9481282 \\
\hline
\end{tabular}

Table 5. HSS Gama 1 Variable

\begin{tabular}{lr}
\hline \multicolumn{1}{c}{ Variable } & \multicolumn{1}{c}{ Result } \\
\hline Peak Time (TR) & 3.0118669 \\
Peak Flood Discharge & 3.2020161 \\
$(\mathrm{Qp})$ & 25.73507 \\
Base Time (TB) & 4.4802595 \\
Recession Coefficient (K) & 12.092583 \\
Base Flow (QB) & 10.477381 \\
Infiltration Index (Q & \\
Index) & \\
\hline
\end{tabular}

The flood discharge is obtained using the HSS Gama 1 method in hourly discharge (hydrograph). From this hydrograph, it can be seen that the trend of increasing and decreasing flow rates in the Badeng watershed. The hydrograph that was formed started from the 0th hour to the 26th hour.
The basis for selecting the hours is obtained from calculating the primary time (TB), which is 25.735 hours or 26 hours. The peak discharge from the Gama 1 method's calculation received a value of $3.202 \mathrm{~m} 3$ / second and the peak time occurred at the 3rd hour. The results of these calculations are 
only based on the physical condition parameters of the Badeng watershed. Therefore, it is necessary to add the effective rain parameters obtained from the rain intensity minus the infiltration index. The
HSS calculation of the flood discharge for each return period can be seen in table 6 . The discharge data will be used as flow data for inundation modeling at HEC-RAS.

Table 6. Flood Discharge of Gama 1 Method

\begin{tabular}{rrrrrrr}
\hline \multirow{2}{*}{$\mathrm{t}($ hour $)$} & \multicolumn{5}{c}{ Flood Discharge Plan } \\
& \multicolumn{1}{c}{ 2 Year } & \multicolumn{1}{c}{5 Year } & \multicolumn{1}{c}{ 10 Year } & 25 Year & 50 Year & 100 Year \\
\hline 0 & 0 & 0 & 0 & 0 & 0 & 0 \\
1 & 24.6096 & 32.37111 & 36.56809 & 41.06606 & 43.96503 & 46.55233 \\
2 & 73.28619 & 98.58811 & 112.2699 & 126.933 & 136.3834 & 144.8178 \\
3 & 130.8166 & 179.9636 & 206.5394 & 235.0211 & 253.3778 & 269.7609 \\
4 & 115.1543 & 162.123 & 187.521 & 214.7404 & 232.2835 & 247.9405 \\
5 & 96.45776 & 139.1559 & 162.2447 & 186.9892 & 202.9372 & 217.1706 \\
6 & 77.16353 & 111.3209 & 129.7912 & 149.5862 & 162.3441 & 173.7305 \\
7 & 61.72869 & 89.05362 & 103.8294 & 119.6648 & 129.8708 & 138.9796 \\
8 & 49.38124 & 71.24043 & 83.06063 & 95.72851 & 103.893 & 111.1798 \\
9 & 39.50362 & 56.99037 & 66.4462 & 76.58016 & 83.11155 & 88.94076 \\
10 & 31.6018 & 45.59071 & 53.15512 & 61.262 & 66.48693 & 71.15014 \\
11 & 25.28056 & 36.47131 & 42.52262 & 49.0079 & 53.1877 & 56.91814 \\
12 & 20.22375 & 29.17603 & 34.01692 & 39.20496 & 42.54869 & 45.53293 \\
13 & 16.17844 & 23.34002 & 27.21259 & 31.36288 & 34.03777 & 36.42508 \\
14 & 12.9423 & 18.67137 & 21.76932 & 25.08944 & 27.22927 & 29.13906 \\
15 & 10.35348 & 14.93658 & 17.41485 & 20.07085 & 21.78266 & 23.31044 \\
16 & 8.2825 & 11.94885 & 13.9314 & 16.05613 & 17.42553 & 18.6477 \\
17 & 6.62577 & 9.558746 & 11.14473 & 12.84446 & 13.93994 & 14.91765 \\
18 & 5.300432 & 7.646732 & 8.915476 & 10.27521 & 11.15156 & 11.9337 \\
19 & 4.240199 & 6.117173 & 7.132134 & 8.219882 & 8.920942 & 9.546632 \\
20 & 3.392042 & 4.893569 & 5.705509 & 6.575678 & 7.136506 & 7.637041 \\
21 & 2.713539 & 3.91472 & 4.564249 & 5.26036 & 5.709007 & 6.109421 \\
22 & 2.170756 & 3.131667 & 3.651273 & 4.208142 & 4.567047 & 4.887367 \\
23 & 1.736545 & 2.505247 & 2.920917 & 3.366397 & 3.653511 & 3.909758 \\
24 & 1.389188 & 2.004128 & 2.336653 & 2.693024 & 2.922708 & 3.127698 \\
25 & 1.111312 & 1.603247 & 1.869257 & 2.154345 & 2.338085 & 2.502072 \\
26 & 0.889018 & 1.282553 & 1.495354 & 1.723416 & 1.870403 & 2.001588 \\
\hline & & & & & &
\end{tabular}

Inundation Modeling.

The first stage in inundation modeling is the creation of a river geometry model. In this study, two methods were used to collect geometric data on the Badeng River. The first way is by direct observation in the field. Direct observations in the field were carried out to get an overview of the field's actual river conditions. The geometrical conditions of rivers in the field can be seen in Figure 3. Next, the second method uses topographic data. The topographic data used are in the form of contour maps.

The contour map used is sourced from the RBI Map for the Banyuwangi Regency area. From the contour map, it is then converted into DEM data using the Topo to Raster method. DEM made with Topo to Raster will be automatically corrected so that the DEM meets hydrological criteria (Indarto and Prasetyo, 2014). 


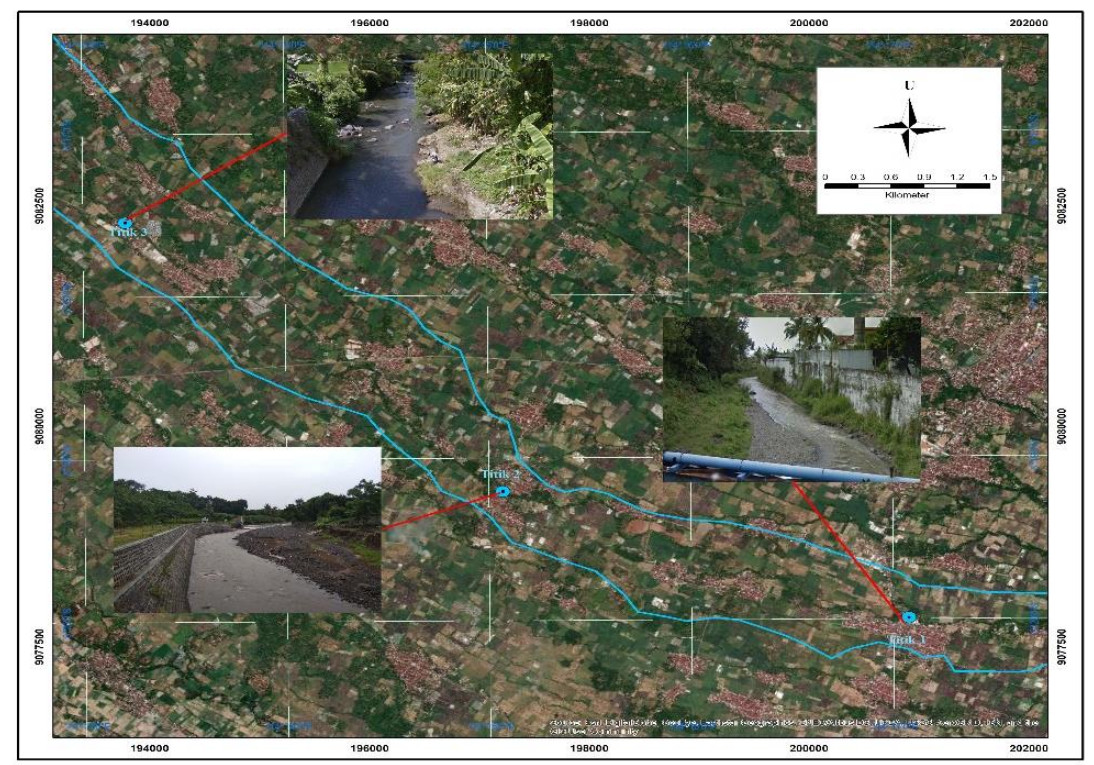

Figure 3. Geometry Condition of Badeng River in the Field

In this study, inundation modeling used 2D simulation. This 2D simulation can model the movement of the flow in the inundated area to make the simulation animation of the Badeng River flow. In addition, the trend of increasing and decreasing river flow depth at a given time is simulated. With this
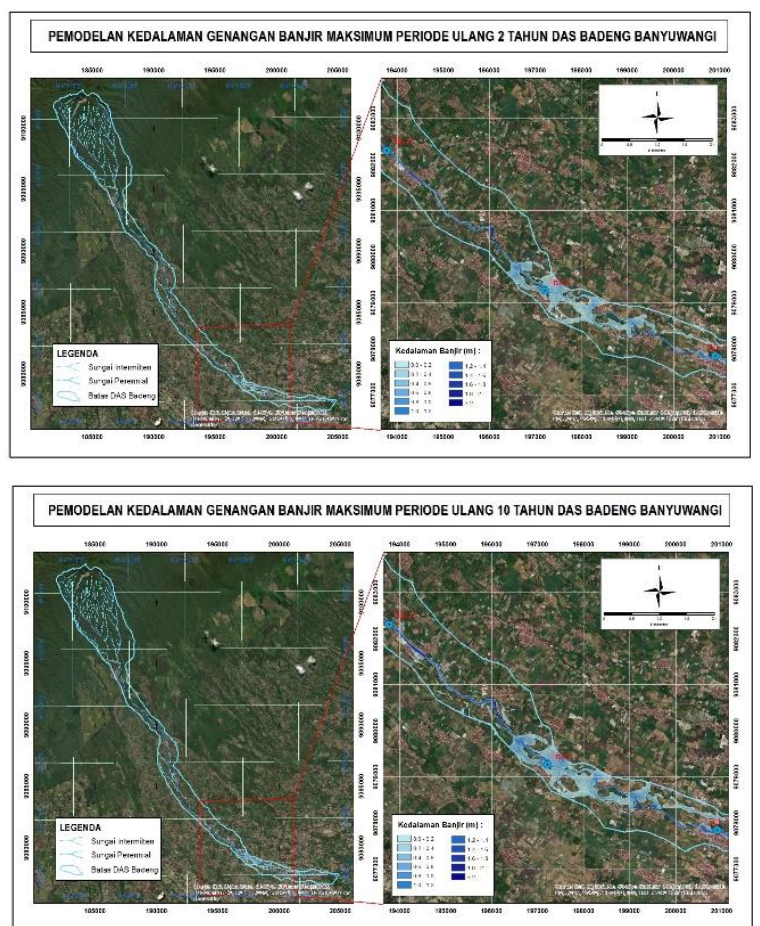

simulation, it is possible to determine the length and depth of flood inundation around the river, which is affected by the river overflow. The results of modeling the flood inundation in the Badeng River can be seen in Figure 4.
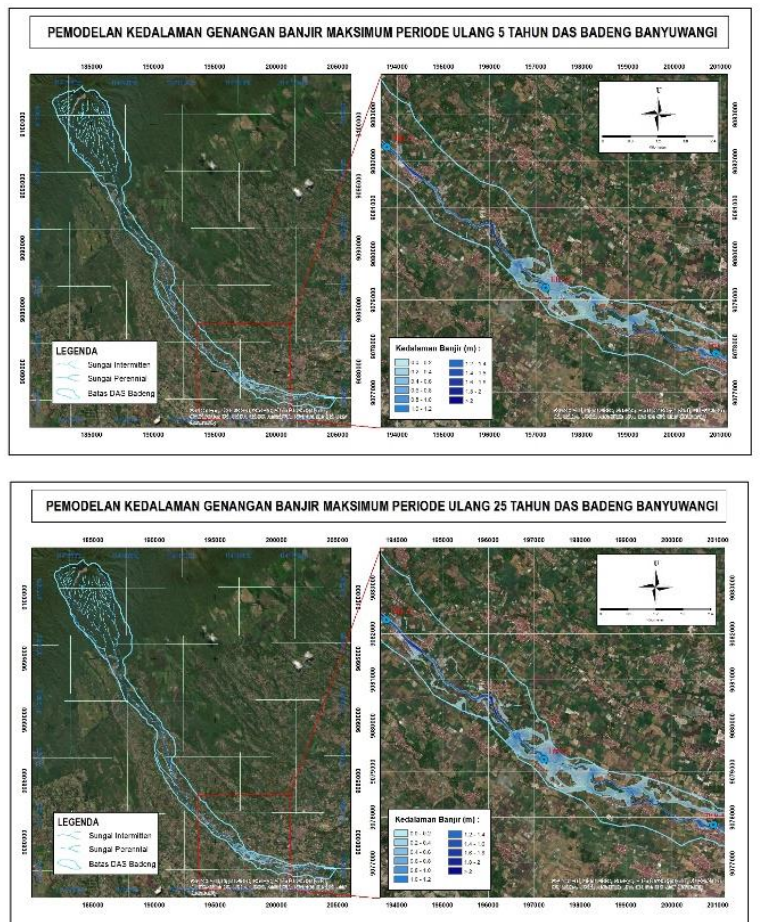

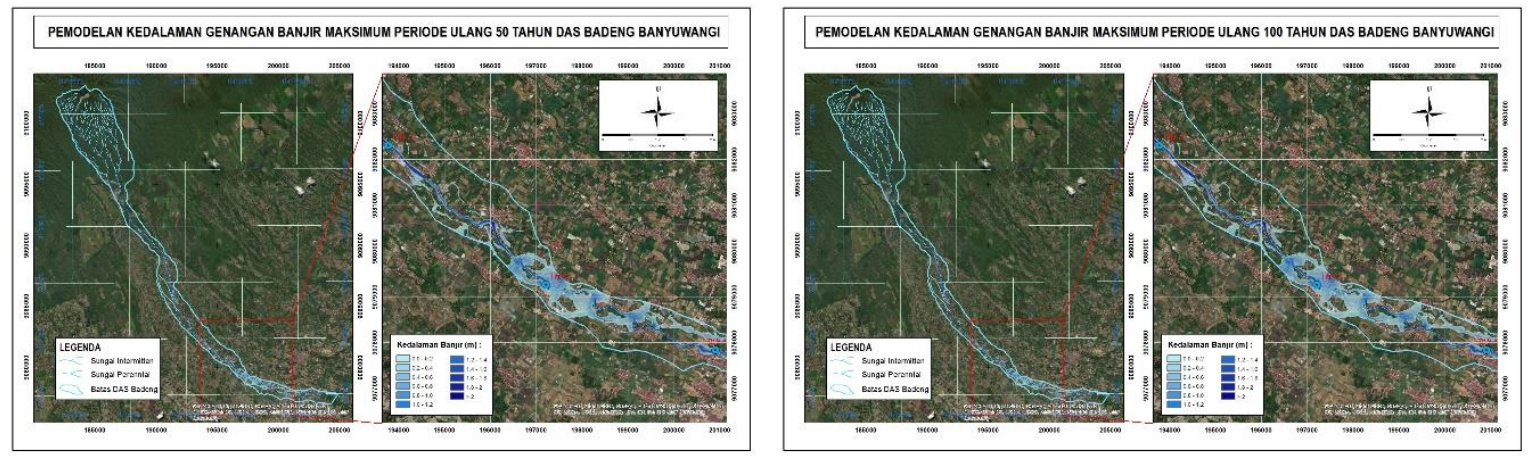

Figure 4. Inundation Modelling Every Return Periods

The simulation results on the HECRAS show differences in the depth and extent of inundation at each return period and at certain times. When there is a peak discharge in the 2 year return period, the inundation depth is 0.1 to 0.6 meters. The affected area is 37.66 hectares with a depth of 0.1 to 0.2 meters; 42.85 hectares with a depth of 0.2 to 0.4 meters; 20.10 hectares with a depth of 0.4 to 0.6 meters. From the simulation results, it can be concluded that the area affected by the inundation is 100.61 hectares.

Inundation simulations at the 5-year return period show the area affected when the peak discharge occurs is 112.53 hectares. The area of impact in the 5 year return period has increased compared to the 2 year return period. The depth of the inundation is in the range 0.1 to 0.6 meters. During this period, the affected area was dominated by an inundation depth of 0.2 to 0.4 meters. The details of the extent and depth of the inundation are 0.1 to 0.2 meter depth of 37.07 hectares; a depth of 0.2 to 0.4 covering an area of 48.48 hectares; a depth of 0.4 to 0.6 covering an area of 26.98 hectares.

The depth of inundation during the 10 year return period increased compared to the 5 year return period. During the 10 year return period, the flood depth is 0.1 to 0.8 meters. The area affected is 133.1 hectares. The details of the extent and depth of inundation in this period are: 0.1 to 0.2 -meter depth of 36.42 hectares; a depth of 0.2 to 0.4 meters covering an area of 53.29 hectares; a depth of 0.4 to 0.6 meters covering an area of 28.72 hectares; a depth of 0.6 to 0.8 meters covering an area of 14.67 hectares. The inundation area in the 10 year return period is dominated by a depth of 0.2 to 0.4 meters.

When the peak discharge occurs, the return period is 25 years, the area affected by inundation is 141.17 hectares. Inundation depth is 0.1 to 0.8 meters. The details of the extent and depth of the inundation at the 25year return period are: 0.1 to 0.2 meter depth of 36.43 hectares; a depth of 0.2 to 0.4 meters covering an area of 55.05 hectares; a depth of 0.4 to 0.6 meters covering an area of 32.20 hectares; a depth of 0.6 to 0.8 meters covering an area of 17.49 hectares. Inundation depth in this period was dominant with a depth of 0.2 to 0.4 meters.

The area affected at the time of the peak discharge for the 50-year return period was 164.23 hectares. Inundation depth ranges from 0.1 to 1 meter. Details of the depth and extent of inundation in this return period, namely: 0.1 to 0.2 meter depth of 39.09 hectares; a depth of 0.2 to 0.4 meters covering an area of 60.31 hectares; a depth of 0.4 to 0.6 meters covering an area of 33.49 hectares; a depth of 0.6 to 0.8 meters covering an area of 20.95 hectares; a depth of 0.8 to 1 meter covering an area of 10.39 hectares. Depths of 0.2 to 0.4 meters have the most dominant area in this period.

The simulation results of inundation during the peak discharge of the 100-year return period showed that the affected area was 170.12 hectares. Inundation depth ranges from 0.1 to 1 meter. The details of the depth and extent of the inundation are as follows: 0.1 to 0.2 meter depth of 39.56 hectares; a depth of 0.2 to 0.4 meters covering an area of 62.44 hectares; a depth of 0.4 to 0.6 meters covering an area of 34.13 
hectares; a depth of 0.6 to 0.8 meters covering an area of 22.56 hectares; a depth of 0.8 to 1 meter covering an area of 11.43 hectares. The most dominant inundation area in this return period is 0.2 to 0.4 meters deep.

The maximum inundation depth occurs around the 6th hour. The most expansive area of inundation also occurred at the 6th hour. The results of the discharge calculation show that the peak time occurs at the 3rd hour. This shows that it takes 3 hours from the upstream of the Badeng watershed to reach the affected location because the maximum river flow arrives at that location at the 6th hour. This time, it shows that the surface runoff occurs quite slowly because it does not occur simultaneously as the peak discharge time. This condition is influenced by the elongated shape of the Badeng watershed. An elongated watershed has a relatively slow concentration-time (Kahirun et al., 2017). The longer a watershed, the farther the river flow travels so that the time needed is also longer.

Based on the simulation results using HEC-RAS, it can be seen that the inundated area is spread over the area around observation point 2 . The cross-sectional condition of the river at observation point 2 is quite wide but shallow. This is due to a large amount of deposition in the river. This sedimentation causes the river holding capacity at observation location 2 to decrease. The river holding capacity at observation location 2 is smaller than the other river cross-sections (Bachri et al., 2019). When the river's carrying capacity cannot accommodate the existing flow, the flow will overflow and inundate the area around the river. Under these conditions, the area around observation point 2 is the area that has the most significant level of flood vulnerability.

\section{Validation Test}

The research results must be carried out as a validation test to determine the suitability between the inundation modeling and events in the field. The validation test in this study used the BPBD disaster data in
Banyuwangi Regency because the recording data of the actual discharge in the Badeng River was not available. Disaster event data used for the validation test were flood disasters in the form of the Badeng River's overflow.

Floods due to the Badeng River's overflow occurred 3 times in 2018 (BPBD Banyuwangi Regency, 2019). The results of the validation test between inundation modeling and BPBD disaster event data are almost close. This can be seen from the considerable inundation height where the modeling results are dominated by 20 to 40 $\mathrm{cm}$. In the BPBD disaster incident data, the dominant inundation height is in the range of 30 to $50 \mathrm{~cm}$. In addition, flow concentration time is also almost close. The flow concentration-time from upstream to the affected area takes 3 hours after the peak discharge occurs in the modeling results.

Meanwhile, based on data on disaster events, the concentration-time required ranges from 2 to 3 hours. In the disaster data, the area most frequently affected by flooding is Alasmalang Village, Singojuruh District. This is also following the inundation modeling results where Alasmalang Village is also one of the areas with a high level of flood vulnerability.

\section{CONCLUSION}

Inundation modeling is required hydrological data and river geometry. The peak discharge of the Gama 1 method shows an increase in each return period. The peak discharge in the Badeng watershed on the flow hydrograph occurred at the 3rd hour. Inundation simulation using the HEC-RAS program shows that the magnitude of the flow rate is directly proportional to the affected area's depth and location. In the simulation at HEC-RAS, the area's maximum depth and location occurred at the 6th hour.

The modeling results show that Alas Malang's village is an area with the most significant inundation potential. These results are also following the data on the disaster incidence of the Banyuwangi BPBD. This area has the smallest river storage 
capacity than other river cross-sections, so it has the most significant potential for flooding. It is necessary to take appropriate anticipatory steps to minimize the losses incurred from future floods.

\section{ACKNOWLEDGMENT}

This paper is the result of the 2019 State University of Malang PNBP research program; therefore, we would like to thank all those who have helped in this research, especially the State University of Malang with the PNBP research program. We would also like to thank the Banyuwangi research team who assisted in data collection.

\section{REREFENCES}

Asdak, C. (2018). Hidrologi dan Pengelolaan Daerah Aliran Sungai. Gadjah Mada University Press.

Bachri, S., Sumarmi, Irawan, L. Y., Aldianto, Y. E., Fathoni, M. N., Fawaid, A. M., Utomo, K. S. B., \& Nuraini, S. G. (2019). Analysis of the Badeng River Storage Capacity for Flood Modeling in Singojuruh Subdistrict, Banyuwangi Regency. 2nd International Conference on Geography and Education, 1-10. https:// doi.org/10.1088/17551315/412/1/012030

BNPB. (2020). Trends in Disasters in the Last 10 Years in Indonesia. https://bnpb.cloud/dibi/

BPBD Kabupaten Banyuwangi. (2019). Data dan Informasi Kejadian Bencana dan Penanganannya di Kabupaten Banyuwangi Tahun 2018.

Farid, M., Marlina, A., Syahril, M., \& Kusuma, B. (2017). Flood hazard mapping of Palembang City by using 2D model Flood Hazard Mapping of Palembang City by using 2D Model. 100009(November). https:// doi.org/10.1063/1.5011619

Hadisusanto, N. (2010). Aplikasi Hidrologi. Jogja Mediautama.

Hadžić, E., Mulaomorević-Šeta, A., Milišić, H., \& Lazović, N. (2018). Estimation of Peak Flood Discharge for an Ungauged River and Application of 1D Hec-Ras Model in Design of Water Levels (pp. 592604). https://doi.org/10.1007/978-3-
319-71321-2_52

Handayani, R., Fauzi, M., \& Hendri, A. (2016). Analisis Besaran Hidrograf Satuan Berdasarkan Karakteristik Daerah Aliran Sungai Siak. Jom FTEKNIK, 3(2), 1-13.

Harijadi. (2015). Analisis Banjir Way Besai Dengan Model Matematis Unsteady Flow Menggunakan Software Hec Ras. Jurnal Rekayasa, 19(1), 13-28.

Indarto, I., \& Prasetyo, D. (2014). Pembuatan Digital Elevation Model Resolusi 10m dari Peta RBI dan Survei GPS dengan Algoritma ANUDEM. Jurnal Keteknikan Pertanian IPB, 2(1), 55-63.

Istiarto. (2014). Modul Pelatihan Simulasi Aliran 1-Dimensi Dengan Bantuan Paket Program Hidrodinamika Hec-Ras Jenjang Dasar: Simple Geometry River. Universitas Gadjah Mada.

Kahirun, S, L. B., \& Hasani, U. O. (2017). Karakteristik Morfometri Menentukan Kondisi Hidrologi DAS Roraya. Jurnal Ecogreen, 3(2), 105-115.

Kuntoro, A. A., Putro, W., \& Kusuma, M. S. B. (2017). The effect of land use change to maximum and minimum discharge in Cikapundung River Basin The Effect of Land Use Change to Maximum and Minimum Discharge in Cikapundung River Basin. 100011(November). https://doi.org/10.1063/1.5011621

Kusratmoko, E., Marko, K., \& Elfeki, A. (2016). Spatial Modelling of Flood Inundation Case Study of Pesangggrahan Floodplain, Jakarta, Indonesia. Journal of Geography, Environment and Earth Science International, 5(3), 1-10. https://doi.org/10.9734/jgeesi/2016/ 23524

Marthina, S., Rapar, E., Mananoma, T., Wuisan, E. M., \& Binilang, A. (2014). Analisis Debit Banjir Sungai Tondano Menggunakan Metode HSS Gama I Dan HSS Limantara. Jurnal Sipil Statik, 2(1), 13-21.

Niipele, J. N., \& Chen, J. (2019). The usefulness of alos-palsar dem data for drainage extraction in semi-arid environments in The Iishana sub-basin. 
Journal of Hydrology: Regional Studies, 21(November 2018), 57-67. https://doi.org/10.1016/j.ejrh.2018.11. 003

Saksono, B. (2018). Kerugian Banjir Ditaksir Rp $5 \mathrm{M}$.

Triadmodjo, B. (2009). Hidrologi Terapan. Beta Offset.
Upomo, T. C., \& Kusumawardani, R. (2016). Pemilihan Distribusi Probabilitas Pada Analisa Hujan Dengan Metode Goodness of Fit Test. Jurnal Teknik Sipil Dan Perencanaan, 18(2), 139-148. https://doi.org/10.15294/jtsp.v18i2.74 80

US Army Corps of Engineers. (2016). HECRAS River Analysis System 2D Modeling User's Manual (Issue Version 5.0). 